Washington (U.S. Government Printing Office), p. 695708.

Fritz, P. and Smith, D. G. W., 1970. The isotopic composition of secondary dolomites: Geochim. Cosmochim. Acta, v. 34 , p. $1161-1173$.

Gonfiantini, R. and Fontes, J. C., 1963. Oxygen isotopic fractionation in the water of crystallization of gypsum: Nature, v. 200, p. 624.

I.A.E.A., 1968-1969. Environmental Isotope Data No. 4: World survey of isotope concentration in precipitation: Tech. Rept. Ser. 147.

Kemp, A. L. W. and Thode H. G., 1968. The mechanism of the bacterial reduction of sulphate and of sulfide from isotope fractionation studies. Geochim. Cosmochim. Acta, v. 32 , p. $71-91$.

Kinsman, D. J. J., 1966. Gypsum and anhydrite of Recent age, Trucial Coast, Persian Gulf. In Second Symposium Salt, v. 1: Northern Ohio Geol. Soc., p. 302-326.

1969. Modes of formation, sedimentary associations, and diagnostic features of shallow water and supratidal evaporites: Am. Assoc. Petrol. Geol. Bull., v. 53, p. $830-840$.

1974. Calcium sulphate minerals of evaporite deposits: their primary mineralogy. In Fourth Symposium Salt: Northern Ohio Geol. Soc., p. 343-348.

Kroopnick, F. and Craig, H., 1972. Atmospheric oxygen: isotopic composition and solubility fractionation: Science, v. 145 , p. $54-55$.

Lloyd, R. M., 1967. Oxygen 18 composition of oceanic sulfate: Science, v. 156 , p. 1228-1231.

1968. Oxygen isotope behavior in the sulfate-water system: J. Geophys. Res., v. 73, p. 6099-6110.

Longinelli, A. and Craig, H., 1967. Oxygen 18, variations in sulfate ions in sea-water and saline lakes: Science, v. 156, p. $56-59$.

Merlivat, L., Botter, R. and Nief, G., 1963. Fractionnement isotopique au cours de la distillation de l'eau: J. Chimie Physique, p. 56-59.

Mizutani, Y. and Rafter, T. A., 1969. Oxygen isotopic composition of sulphates: Part 4: bacterial fractionation of oxygen isotopes in the reduction if sulphate and in the oxydation of sulphur: New Zealand J. Sci., v. 12, p. 60-68. , 1973. Isotopic behavior of sulphate oxygen in the bacterial reduction of sulphate: Geochem. J., v. 6, p. 183191.
Nakai, N. and Jensen, M. L., 1964. The kinetic isotope effect in the bacterial reduction and oxydation of sulfur: Geochim. Cosmochim. Acta, v. 28, p. 1893-1912.

Nir, A., 1967. Development of isotope methods applied to ground-water hydrology. In Isotope techniques in the hydrologic cycle: Monogr. 11, Am. Geophys. Union, Washington D.C., p. 109-116.

Northrop, D. A. and Clayton, R. N., 1966. Oxygen isotope fractionation in systems containing dolomite: J. Geol., v. 74, p. 174-196.

O'Neil, J. R. and Epstein, S., 1966. Oxygen isotope fractionation in the system dolomites-calcite-carbon dioxide: Science, v. 152, p. 198-201.

Pierre, C., 1974. Contribution à l'étude sédimentologique et isotopique des évaporites messiniennes de la Méditerranée; implications géodynamiques: Thèse, Paris.

Rafter, T. A. and Mizutani, Y., 1967. Preliminary study of variations of oxygen and sulphur isotope in natural sulphates: Nature, v. 216 , p. 1000-1002

Ryan, W. B. F., Hsü, K. J., et al., 1973. Initial Reports of the Deep Sea Drilling Project, Volume 13: Washington (U.S. Government Printing Office).

Sasaki, A., 1972. Variation in sulphur isotopic composition of oceanic sulphate: Twenty-four Congr. Geol. Int., Montréal-Ottawa.

Sharma, T. and Clayton, R. N., 1965. Measurement of ${ }^{18} \mathrm{O} /$ ${ }^{16} \mathrm{O}$ ratios of total oxygen of carbonates: Geochim. Cosmochim. Acta, v. 29, p. 1347-1353.

Shearman, D. J., 1966. Origin of marine evaporites by diagenesis. Inst. Mining Metallurgy Trans., p. $75-208$

Thode, H. G. and Monster, J., 1965. Sulfur isotope geochemistry of petroleum, evaporites and ancient seas. in: Fluids in subsurface environments: Am. Assoc. Petrol. Geol. Mem. 4, p. 367-377.

Thode, H. G., Monster, J., and Dunford, H. B., 1961. Sulphur isotope geochemistry. Geochim. Cosmochim. Acta, v. 26, p. $159-174$.

Weber J. N., 1964. Oxygen isotope fractionation between coexisting calcite and dolomite: Science, v. 145 , p. 13031305 .

1965. Oxygen isotope fractionation between coexisting calcite and dolomite in the freshwater upper carboniferous Freeport Formation: Nature, v. 207, p. $972-973$.

\title{
26.2. STABLE ISOTOPIC INVESTIGATION OF CARBONATE SAMPLES RELATED TO THE MESSINIAN SALINITY CRISIS FROM DSDP LEG 42A, MEDITERRANEAN SEA
}

\author{
J. A. McKenzie, Swiss Federal Institute of Technology, Zürich, Switzerland \\ and \\ T. E. Ricchiuto, Laboratorio Geologia Nucleare Università di Pisa, Italy
}

\begin{abstract}
The oxygen-18 and carbon-13 ratios were measured on a series of carbonate samples selected from two different Messinian sequences: the marine deposits of the intra-Messinian and the Lago Mare deposits at the end of the Messinian. The intra-Messinian
\end{abstract}

\footnotetext{
${ }^{1}$ Present address: AGIP-AMI, Servizio SGEL, I-20097 S. Donato Milanese, Milano, Italy.
} 
carbonates from Site 372, Balearic Basin, isotopically reflected changes in salinity and circulation patterns as the basin moved from open marine to conditions of evaporite deposition. The isotopic study of the Lago Mare deposits from two eastern Mediterranean sites showed the non-equivalency of sedimentary developments in two separate basins. Extreme evaporation and unusual stagnant conditions are postulated to have produced the relatively heavy oxygen-18 and carbon-13 ratios found for the dolomitic sediments from Site 374, Ionian Basin. Relatively less severe conditions must have prevailed at Site 376, Antalya Basin, where the influx of continental water was particularly notable in the depleted stable isotope ratios of the predominantly calcitic sediments.

\section{INTRODUCTION}

The existence of deep desiccated, inland basins in the upper Miocene Mediterranean was postulated to explain the vast evaporite deposits discovered during DSDP Leg 13 (Ryan, Hsü, et al., 1973). Stable isotope studies of Messinian carbonates, sampled during Leg 13, had established the importance of a meteoric origin for the waters flowing into these basins (Lloyd and Hsü, 1973; Fontes et al., 1973; and Lawrence, 1973). With Leg 42A, a further sampling of the Messinian carbonates provided an opportunity to continue the isotopic studies in order to interpret the depositional and diagenetic histories of the desiccated basins. The purpose of this work was to use stable isotope geochemistry to evaluate environmental changes that may have occurred during and after the deposition of the Messinian evaporites.

\section{PROCEDURE}

The carbonate samples were washed in distilled water to remove dissolvable salts and heated in a helium stream at $450^{\circ} \mathrm{C}$ for 30 minutes to release organic constituents. The samples were then reacted with $100 \%$ phosphoric acid according to the standard technique used to obtain $\mathrm{CO}_{2}$ for mass spectrometric analysis (McCrea, 1950). X-ray diffraction scans were run on all analyzed samples to determine quantitatively the percent of dolomite present with respect to the total carbonate content. In general, for carbonate mixtures in which the percent dolomite was between 20 and $50 \%$, a chemical separation was undertaken during the phosphoric acid reaction to obtain $\mathrm{CO}_{2}$ gas from both the calcite and the dolomite fractions (Epstein et al., 1964). The small particle size (5 to $10 \mu)$ was taken into consideration when determining the reaction times for the chemical separation (Walters et al., 1972).

The isotopic values are reported in Tables 1,2, and 3. Data listed under bulk carbonate are for analyses made on the total gas evolved during the preparation. Data listed under the columns Calcite and Dolomite are for analyses of the respective gas portions from double extractions made on a single sample. The isotopic results are given in the $\delta$-terminology $(\% \circ)$ relative to the PDB standard. The oxygen- 18 ratios for the dolomite analyses have been corrected by a factor of $0.8 \%$ (Sharma and Clayton, 1965). Figure 1 shows the location of the DSDP sites where the analyzed samples were recovered.

\section{DISCUSSION OF RESULTS}

\section{Intra-Messinian Carbonates}

At Site 372 on the East Menorca Rise, Balearic Basin, the deep sea drilling penetrated a thin wedge of the Messinian upper evaporite unit and recovered carbonate sediments of the intra-Messinian. These sediments represent a time of marine deposition between the lower and upper evaporite units, a time when there was a renewed influx of Atlantic water into the Mediterranean (Hsü et al., this volume). Although over 600 meters of sediment were cored beneath the evaporite, only Sections 1 and 2 of Core 9 are of interest to this study. An unconformity separates the nannofossil marls of the intra-Messinian from the nannofossil marls below (Hsü et al., this volume). The isotopic content of the carbonates found below Core 9, Section 2 remained constant well into the middle Miocene (McKenzie et al., this volume). It is in Core 9, Section 2 that isotopic changes indicative of the renewed onset of evaporation are seen.

Moving upward through Core 9, the oxygen-18 content of the carbonate sediments becomes progressively, although only slightly, more positive. See Table

TABLE 1

Stable Isotope Analyses of Carbonates From Site 372, Balearic Basin

\begin{tabular}{|c|c|c|c|c|}
\hline \multirow[b]{2}{*}{$\begin{array}{l}\text { Sample (In- } \\
\text { terval in cm) }\end{array}$} & \multirow[b]{2}{*}{ Description } & \multirow{2}{*}{$\begin{array}{c}\text { Dolomite of } \\
\text { Total Carbonate } \\
(\%)\end{array}$} & \multicolumn{2}{|c|}{ Bulk Carbonate } \\
\hline & & & $\delta \mathrm{O}_{\mathrm{PDB}}^{18}$ & $\delta \mathrm{C}_{\mathrm{PDB}}^{13}$ \\
\hline $9-1,87-88$ & & 8 & +2.0 & -5.6 \\
\hline $9-1,92-93$ & & 0 & +1.9 & -4.5 \\
\hline \multirow[t]{3}{*}{$9-1,104-105$} & light grey & 0 & +2.4 & -4.7 \\
\hline & It. \& dk. grey & 0 & +1.9 & -4.4 \\
\hline & dark grey & 15 & +1.4 & -4.2 \\
\hline \multirow[t]{2}{*}{$9-1,123-124$} & light grey & 19 & -0.4 & -3.6 \\
\hline & dark grey & 7 & +0.4 & -3.1 \\
\hline $9-1,135-137$ & & 8 & +1.1 & -2.7 \\
\hline $9-2,0-1$ & & 7 & +1.0 & -4.1 \\
\hline \multirow[t]{3}{*}{$9-2,8-9$} & light grey & 11 & +0.8 & -2.4 \\
\hline & medium grey & 5 & +1.0 & -2.8 \\
\hline & dark grey & 5 & +0.4 & -2.9 \\
\hline $9-2,45-47$ & & 18 & +1.1 & -3.6 \\
\hline $9-2,64-65$ & & 6 & +0.5 & -0.2 \\
\hline $9-2,114-116$ & & 25 & +0.4 & -0.8 \\
\hline $9-2,135-136$ & & 10 & +0.3 & +0.5 \\
\hline
\end{tabular}


TABLE 2

Stable Isotope Analyses of Carbonates From Site 374, Ionian Basin

\begin{tabular}{|c|c|c|c|c|c|c|c|c|}
\hline \multirow[b]{2}{*}{$\begin{array}{c}\text { Sample } \\
\text { (Interval in } \mathrm{cm} \text { ) }\end{array}$} & \multirow[b]{2}{*}{ Depth (m) } & \multirow{2}{*}{$\begin{array}{c}\text { Dolomite of } \\
\text { Total Carbonate } \\
(\%)\end{array}$} & \multicolumn{2}{|c|}{ Bulk Carbonate } & \multicolumn{2}{|c|}{ Calcite } & \multicolumn{2}{|c|}{ Dolomite } \\
\hline & & & $\delta \mathrm{O}_{\mathrm{PDB}}^{18}$ & $\delta \mathrm{C}_{\mathrm{PDB}}^{13}$ & $\delta \mathrm{O}_{\mathrm{PDB}}^{18}$ & $\delta \mathrm{C}_{\mathrm{PDB}}^{13}$ & $\delta \mathrm{O}_{\mathrm{PDB}}^{18}$ & $\delta \mathrm{C}_{\mathrm{PDB}}^{13}$ \\
\hline $26(\mathrm{SW})^{\mathrm{a}}, 1-2$ & 370 & 16 & +1.8 & +1.0 & & & & \\
\hline $26(\mathrm{SW}), 17-18$ & 370 & 17 & +2.0 & +1.0 & & & & \\
\hline $25(\mathrm{SW}), 3-4$ & 375 & 100 & +4.1 & +1.1 & & & & \\
\hline $25(\mathrm{SW}), 21-22$ & 375 & 100 & +4.3 & +1.5 & & & & \\
\hline $25(\mathrm{SW}), 31-33$ & 375 & 100 & +4.9 & +1.9 & & & & \\
\hline 25 (SW), $40-41$ & 375 & 100 & +4.8 & +1.0 & & & & \\
\hline $11-1,80-81$ & 378.8 & 53 & & & +0.9 & -0.2 & +4.7 & +1.8 \\
\hline $11-2,25-29$ & 379.9 & 96 & +4.1 & +0.8 & & & & \\
\hline $11-2,66-69$ & 380.2 & 95 & +3.5 & +0.2 & & & & \\
\hline $11-2,90-92$ & 380.4 & 95 & +7.7 & +9.9 & & & & \\
\hline $11-2,147-149$ & 381.0 & 95 & +4.5 & +1.2 & & & & \\
\hline $13-2,50-52$ & 389.5 & 100 & +9.7 & +13.8 & & & & \\
\hline $14-1,77-78$ & 393.3 & 92 & +6.0 & +3.9 & & & & \\
\hline $15-1,44-45$ & 397.4 & 88 & +6.9 & +7.0 & & & & \\
\hline $17-1,80-82$ & 411.8 & 100 & +6.4 & -4.0 & & & & \\
\hline $19-1,22-23$ & 418.2 & 90 & +7.2 & -3.7 & & & & \\
\hline
\end{tabular}

asidewall core.

TABLE 3

Stable Isotope Analyses of Carbonates From Site 376, Antalya Basin

\begin{tabular}{|c|c|c|c|c|c|c|c|c|}
\hline \multirow[b]{2}{*}{$\begin{array}{c}\text { Sample } \\
\text { (Interval in } \mathrm{cm} \text { ) }\end{array}$} & \multirow[b]{2}{*}{ Depth (m) } & \multirow{2}{*}{$\begin{array}{c}\text { Dolomite of } \\
\text { Total Carbonate } \\
(\%)\end{array}$} & \multicolumn{2}{|c|}{ Bulk Carbonate } & \multicolumn{2}{|c|}{ Calcite } & \multicolumn{2}{|c|}{ Dolomite } \\
\hline & & & $\delta \mathrm{O}_{\mathrm{PDB}}^{18}$ & $\delta \mathrm{C}_{\mathrm{PDB}}^{13}$ & $\delta \mathrm{O}_{\mathrm{PDB}}^{18}$ & $\delta \mathrm{C}_{\mathrm{PDB}}^{13}$ & $\delta \mathrm{O}_{\mathrm{PDB}}^{18}$ & $\delta \mathrm{C}_{\mathrm{PDB}}^{13}$ \\
\hline $6-4,30-31$ & 50.3 & 15 & -0.1 & +1.0 & & & & \\
\hline $6-4,55$ & 50.6 & 6 & +2.0 & +1.4 & & & & \\
\hline $6-4,100$ & 51.0 & 5 & -0.7 & -0.2 & & & & \\
\hline $7-1,40-41$ & 55.4 & 4 & +4.5 & -0.9 & & & & \\
\hline $7-1,57-58$ & 55.6 & 44 & & & -3.5 & -1.8 & +2.6 & -1.0 \\
\hline $7-1,79-80$ & 55.8 & 47 & & & -3.9 & -1.8 & +2.9 & -1.7 \\
\hline $7-1,107-108$ & 56.1 & 47 & & & -3.6 & -2.3 & +2.4 & -1.4 \\
\hline $7-2,102-103$ & 57.5 & 25 & & & -2.1 & -1.7 & +1.0 & -1.9 \\
\hline $8-2,19-20$ & 66.2 & 16 & & & -3.3 & -0.8 & 0.0 & -1.0 \\
\hline $9-4,72-73$ & 79.2 & 29 & & & -1.6 & -3.6 & +1.5 & +0.7 \\
\hline $10-3,24-25$ & 86.7 & 12 & -3.1 & -3.5 & & & & \\
\hline $11-2,83-84$ & 95.3 & 8 & -1.8 & -2.5 & & & & \\
\hline $11-2,108-111$ & 95.6 & 0 & +0.8 & +0.2 & & & & \\
\hline $11-2,118-121$ & 95.7 & 0 & -1.6 & -0.8 & & & & \\
\hline $12-5,113-114$ & 109.6 & 0 & -0.6 & -1.3 & & & & \\
\hline $13-4,52-53$ & 117.0 & 0 & -0.1 & -1.2 & & & & \\
\hline $15-2,107-108$ & 113.6 & 5 & -3.2 & -2.7 & & & & \\
\hline $16-1,45-46$ & 141.0 & 3 & -2.4 & -2.5 & & & & \\
\hline $17-1,50-51$ & 150.5 & 0 & -1.7 & -0.7 & & & & \\
\hline
\end{tabular}

1. The change in the carbon- 13 content is more dramatic. Between Samples 372-9-2, 64-65 cm, and 372$9-2,45-47 \mathrm{~cm}$, there is a significant depletion in carbon- 13 by $3.5 \%$. This depletion continues to a low $\delta \mathrm{C}^{13}$ PDB value of $-5.6 \%$ at Sample 372-9-1, 87$88 \mathrm{~cm}$. The isotopic data suggest that the upper carbonate sediments in Core 9 were formed in a totally or partially closed basin from a reservoir of carbonate ions progressively depleted in carbon-13 and enriched in oxygen-18. The latter enrichment probably reflects an increase in the oxygen-18 content of the basin's water as a result of evaporation. The sharp depletion in carbon-13 ions indicates a significant increase in the amount of carbonate ions having an organic origin. The transfer from an open marine to an evaporating basin may have changed the circulation pattern resulting in euxinic conditions. Increased production of $\mathrm{CO}_{2}$ from the decomposition of organic material could have occurred in the stagnant layers. Therefore, as the basin approached the evaporitic phase of deposition, the associated carbonate sediments would be depleted in carbon-13 with respect to those from open marine sedimentation.

The sediments of Core 9 were frequently thinly laminated. The isotopic content of the different lamina does not show a consistent pattern of variation. The fact that the isotopic values do vary from layer to layer may indicate frequent alteration in the salinity and redox conditions of the basin prior to the onset of the evaporite deposition.

\section{Lago Mare Carbonates}

Near the end of the Messinian salinity crisis, the deep desiccated basins in the eastern Mediterranean 
were flooded by an influx of water from the Paratethys. The sediments deposited after the inundation belong to the Lago Mare sequence, which spans the transition from the top of the Messinian evaporites to the early Pliocene (Hsü et al., this volume). Carbonate samples from the Lago Mare sequence of two basins, the Ionian and the Antalya, were available for this isotopic study.

At Site 374 on the Ionian Abyssal Plain, dolomite is the dominant carbonate mineral of the Lago Mare marls. In most samples the dolomite percentage of the total carbonate approaches $100 \%$. The dolomite samples analyzed for this study are of two distinct types. Cores 12 to 19 contain dark grey, dolomitic marlstones often in association with the Messinian gypsum deposits. The dolomite in the marlstones is most likely a primary precipitate or an early diagenetic replacement product. The sediment of Core 11 is a dolomitized, early Pliocene pelagic limestone. This replacement dolomite has an unusual crystal habit. The crystals have a platy structure, which changes gradually towards a more rhombohedral form in the lower part of Core 11, Section 2. The contact between the two dolomite facies has not been sampled but is probably a disconformity rather than a gradual transition. (Bernoulli and Mélières, this volume).

The stable isotopic ratios of the Site 374 dolomites show a large variation, which probably represents changes in the isotopic composition of the Lago Mare waters. The $\delta \mathrm{O}^{18} \mathrm{PDB}$ of the dolomitic marlstone ranges from +6.0 to $+9.7 \%$, while $\delta \mathrm{C}^{13} \mathrm{PDB}$ ranges from -4.0 to $+13.8 \%$. See Table 2 . The high, variable oxygen-18 content is not unusual for dolomite precipitated from evaporated waters. The $\delta \mathrm{O}^{18}$ ratios of the dolomite indicate that the isotopic content of the Lago Mare water had been highly enriched by extreme and repeated evaporation. This enrichment isotopically obscures the meteoric origin of the waters in the Ionian Basin during the Lago Mare deposition.

More unusual than the relatively positive $\delta \mathrm{O}^{18}$ ratios is the variation from negative to positive values in the $\delta \mathrm{C}^{13}$ ratios. Such variations, although not frequent, have been recorded elsewhere. Extreme light and heavy carbon-13 contents were found for dolomites within the same outcrops of the Permian Irati Formation, Parana Basin, southern Brazil. The lighter carbon values were associated with a grey, massive dolomite containing small amounts of organic matter, whereas the heavier carbon values were found in a zone containing interbedded, thin layers of organic-rich shale and dolomite (De Giovani et al., 1974). Another example of unusually heavy carbon-13 values in dolomites with a mean $\delta \mathrm{C}^{13}$ PDB of $+8.2 \pm 2.6 \%$ was reported for the Precambrian Lomagundi carbonate province, Rhodesia (Schidlowski et al., 1976). These anomalously high values were found for carbonate samples covering an extensive area. To obtain such an elevated carbon-13 content, it was concluded that the dolomite formed in a closed basin under stagnant or evaporitic conditions in which the carbon- 13 content had been substantially increased through the preferential removal of carbon-12 into sedimentary organics.
A second explanation for dolomites with variable heavy carbon and relatively constant heavy oxygen was presented by Murata et al. (1969) to explain such isotopic values found for carbonates of the marine Miocene formations of California and Oregon. They suggested that the heavy carbon comes from an isotopic equilibration between $\mathrm{CO}_{2}$ and $\mathrm{CH}_{4}$. With this mechanism the equilibrated $\mathrm{CH}_{4}$ is significantly depleted in carbon-13, while the $\mathrm{CO}_{2}$ and the resultant carbonates are enriched.

At Site 374 , the dolomites with negative $\delta \mathrm{C}^{13} \mathrm{PDB}$ ratios (Cores 17 and 19) undoubtedly received part of their carbon from an organic source, probably from biogenic decay within the basin. The gypsiferous mudstones of Cores 16 to 21 are especially rich in organic matter, enough to have qualified as sapropels in a marine sequence (Site 374 Report, this volume). In fact, Deroo et al. (this volume) report that the organic matter of the Messinian evaporitic levels of Site 374 could be of marine or lacustrine origin. This would indicate that during this time there were episodes of stagnation of the bottom waters in the basin. Perhaps, the effect of this alternating stagnation and evaporitic episodes was felt isotopically until the end of the Messinian as a consequence of either (1) the deposition of organic matter which depleted the lighter carbon isotopes in the closed basin or (2) the release of methane in the stagnant bottom waters which equilibrated with $\mathrm{CO}_{2}$ resulting in isotopically heavy carbonate ions. Or, the carbon-13 contents may reflect a combination of both effects. Also, it is interesting to note that Sigl et al. (this volume) report unexplainably low carbon-13 contents for the organic material found in cores from Site 374, including those of the Miocene evaporitic sections.

The isotopic values of the samples from Core 11 and Sidewall Core (SW) 25 are for the diagenetic, platy dolomite. They are not particularly unusual values for a deep-sea dolomite, although the carbon-13 content indicates a partial biogenic origin of $\mathrm{CO}_{2}$ (Fontes and Desforges, 1975). On the other hand, the isotopic ratios of Sample 374-11-2, 90-92 cm, make its positioning uncertain as it appears to resemble more the Messinian dolomites. Perhaps, this sample represents a boundary between diagenetic solutions originating in the stagnant, evaporitic basin and in an open marine environment. The increasing rhombohedral nature of the dolomites in the lower part of Core 11, Section 2 may also be another result of formation from a different solution. The analysis of more samples is required to obtain a better understanding of what transpired.

The stable isotope ratios of the Sidewall Core 26 carbonates indicate a return to normal marine conditions.

At Site 376 on the Florence Rise, Antalya Basin, the Lago Mare sediments are nannofossil marlstones sometimes dolomitic but mainly calcitic. Significant amounts of dolomite are found only in the upper cores approaching the Miocene/Pliocene boundary. Negative values were found for the oxygen and carbon isotopic 


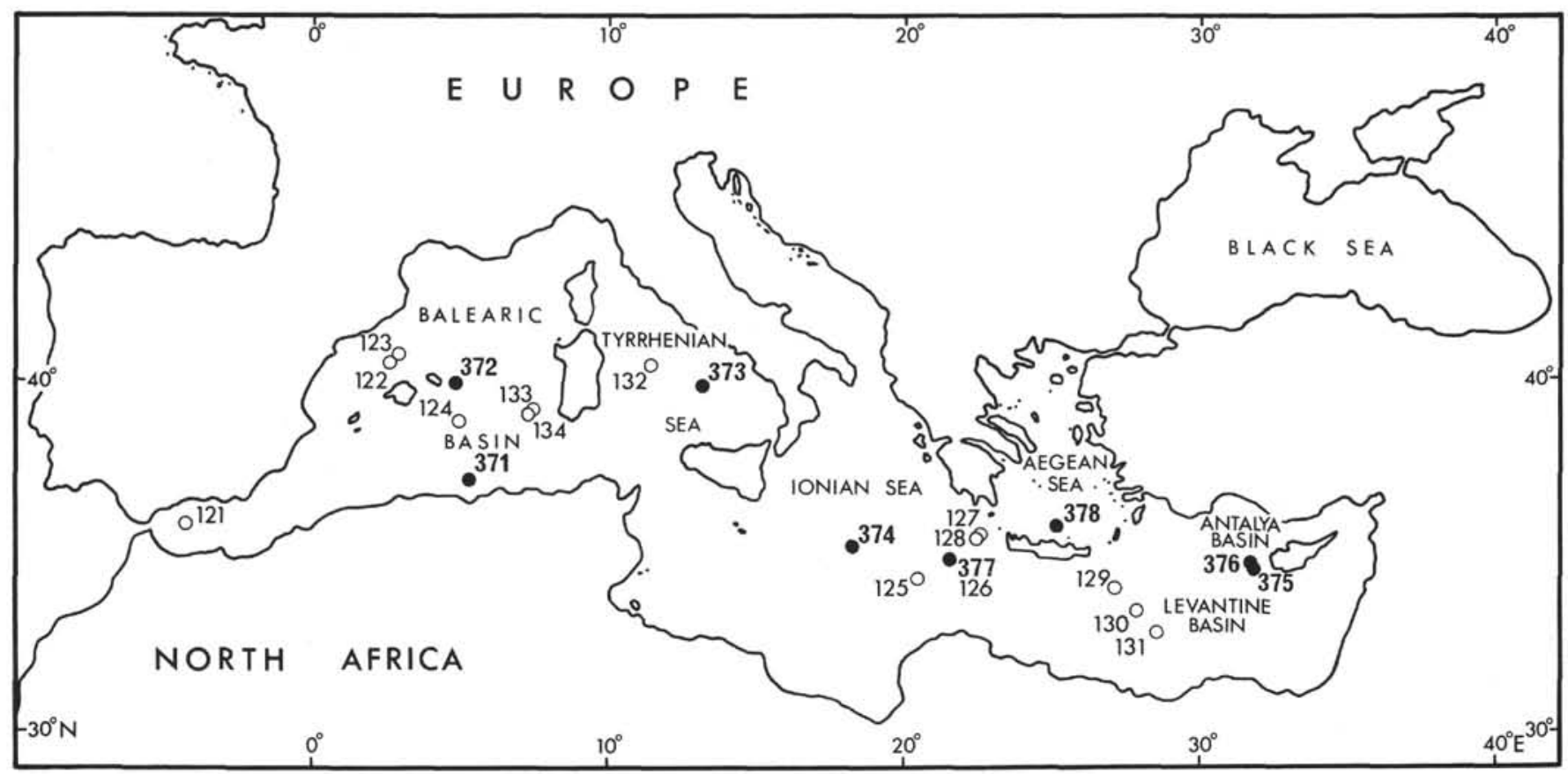

Figure 1. Map of the Mediterranean Sea showing site locations of DSDP Leg $42 \mathrm{~A}$ in relation to those of Leg 13 sites.

ratios of the calcite samples. See Table 3. Even the calcite intercalcated with the gypsum sequence (Sample $376-17-1,50-51 \mathrm{~cm}$ ) had negative ratios. The dolomite samples from Cores 7 to 9 also had negative $\delta \mathrm{C}^{13}$ ratios and rather low but positive $\delta \mathrm{O}^{18}$ ratios. All of these isotopic values are indicative of a significant influx of continental water into the Messinian basin. Once in the basin, the water surely experienced evaporation, which increased its oxygen-18 content. The carbonate sediments were precipitated from a brackish meteoric water. The variability of the $\delta \mathrm{O}^{18}$ ratios probably represents fluctuations in the amount of fresh water input versus evaporation. It may also represent slight changes in the temperature of the water. A study of west Texas lake carbonates from the Pliocene revealed a similar, rapid variability in their isotopic composition (Parry et al., 1970). It was concluded that this variation resulted from the isotopic alteration of the lake water under extreme climatic conditions. The slightly negative and variable $\delta \mathrm{C}^{13} \mathrm{PDB}$ values for the Lago Mare carbonates reflect a terrestrial input of carbonate ions or organic decomposition within the basin.

The isotopic data for the Site 376 Lago Mare sediments is in agreement with the paleontological studies, which indicate the existence of a shallow euryhaline environment at this site during the late Miocene (Site 376 Summary, this volume). For comparison, it is interesting to note that stable isotopic values for the carbonate sediments associated with late Miocene evaporites in the Red Sea are likewise negative (Supko et al., 1974). In fact, the isotopic ratios of the Red Sea carbonates are more depleted than those from the Antalya Basin. The authors propose that these negative values are the result of fresh water influxes into the evaporatic basin, which lowered the $\delta \mathrm{O}^{18}$ ratio of the water. Perhaps, then, the Red Sea carbonate sediments are synchronous to the Lago Mare deposits of the eastern Mediterranean.

The confused nature of the isotopic values at the Miocene/Pliocene boundary (Sample 376-7-1, 40-41 $\mathrm{cm}$ to $376-6-4,30-31 \mathrm{~cm}$ ) reflects the greatly disturbed nature of Core 6, Section 4, where Pliocene marls were found under the Miocene. This has been explained by both downslope slumping and downhole contamination (Site 376 Summary, this volume). Therefore, the isotopic results are inconclusive due to the possible mixing that may have occurred.

\section{CONCLUSIONS}

The carbonate sediments analyzed in this study were from two different intervals of the Messinian salinity crisis. The stable isotopic analyses of these samples produced general information concerning the environment of deposition during these intervals.

The first sequence of sediments investigated were deposited during the intra-Messinian interval, the period in which marine sedimentation occurred between the upper and lower evaporite units (Hsü et al., this volume). The analyzed samples were nannofossil marls from Site 372, Balearic Basin. They showed a gradual increase in $\delta \mathrm{O}^{18}$ PDB from +0.5 to $+2.0 \%$ 。 with a more dramatic decrease in $\delta \mathrm{C}^{13}$ PDB from -0.2 to $-5.6 \%$. These isotopic variations were interpreted as indicators of changes in the aqueous environments prior to renewed evaporite deposition, i.e., increased salinity accompanied by reduced circulation and stagnation within the basin.

The second interval studied pertained to the Lago Mare deposits from the eastern Mediterranean. These are transitional sediments which span the time interval from the top of the Messinian evaporites to the early 
Pliocene (Hsü et al., this volume). This transition was studied isotopically in a sequence of carbonate samples from two eastern Mediterranean basins. The sedimentary developments in the basins were not identical. The Lago Mare transition was marked in individual basins by differing environments.

In the Ionian Basin, Site 374, the deeper of the two studied, the Lago Mare was a stagnant body of water from which dolomite appears to have either precipitated or been an early diagenetic replacement product. Quite possibly, the water in this basin had a meteoric origin, but with extreme and repeated evaporation its isotopic content became highly enriched. The dolomite had very enriched $\delta \mathrm{O}^{18}$ PDB ratios ranging from +6 to $+10 \%$. The accompanying salinity stratification and stagnation produced unusual conditions, which were reflected in an alteration of the carbon isotopic ratios in the carbonate ions. The carbonate of lower cores was depleted in carbon- 13 at a $\delta \mathrm{C}^{13}$ PDB ratio of $-4 \%$. Carbonate in subsequent cores was highly enriched in carbon-13, as great as a $\delta \mathrm{C}^{13}$ PDB ratio of $+14 \%$. This carbon- 13 enrichment may be related to extensive organic sedimentation in a closed, stagnant basin.

The Lago Mare in the Antalya Basin, Site 376, was a shallow, brackish water body conducive to the support of euryhaline fauna. Calcium carbonate was the dominant carbonate mineral with isotopic ratios ranging from -4 to $0 \%$ for $\delta \mathrm{O}^{18} \mathrm{PDB}$ and -3.5 to 0 $\%$ for $\delta \mathrm{C}^{13}$ PDB. Under these less severe conditions the stable isotopic compositions of the carbonates reflect the continental origin of the water and a terrestrial input or biogenic origin for a portion of the carbonate ions.

\section{ACKNOWLEDGMENT}

We would like to thank K. J. Hsü, A. Longinelli, and G. Cortecci for stimulating discussions during the course of this work, which was carried out at the Laboratorio di Geologia Nucleare, Pisa, Italy, and was supported by the Swiss National Science Foundation Grant Number 2.765-0.72 and by C.N.R.-University of Pisa Grant Number 74.00723 .

\section{REFERENCES}

De Giovani, W. F., Salati, E., Marini, O. J., and Friedman, I., 1974. Unusual isotopic composition of carbonates from the Irati Formation, Brazil: Geol. Soc. Am. Bull., v. 85, p. 41-44.

Epstein, S., Graf, D. L., and Degens, E. T., 1964. Oxygen isotope studies on the origin of dolomite. In Craig, H., Miller, S. L., and Wasserburg, G. T., (Eds.) Isotopic and cosmic chemistry: Amsterdam (North Holland Publ. Co.), p. 169-180.
Fontes, J. C. and Desforges, G., 1975. Oxygen 18, carbon 13 and radiocarbon as indicators of a Würmian cold and deep diagenesis in western Mediterranean carbonate sediments: IX Congres International de Sedimentologie, Nice, Theme 8, p. 29-38.

Fontes, J. C., Letolle, R., Nesteroff, W. D., and Ryan, W. B. F., 1973. Oxygen, carbon, sulfur, and hydrogen stable isotopes in carbonate and sulfate mineral phases of Neogene evaporites, sediments and in interstitial waters, Leg 13. In Ryan, W. B. F., Hsü, K. J., et al., Initial Reports of the Deep Sea Drilling Project, Volume 13: Washington (U.S. Government Printing Office), p. 788796.

Lawrence, J. R., 1973. Stable oxygen and carbon isotope variations in bulk carbonates from late Miocene to present, in Tyrrhenian BasinSite 132. In Ryan, W. B. F., Hsü, K. J., et al., Initial Reports of the Deep Sea Drilling Project, Volume 13: Washington (U.S. Government Printing Office), p. 796-798.

Lloyd, R. M. and Hsü, K. J., 1973. Preliminary isotopic investigations of samples from deep sea drilling in the Mediterranean Sea. In Ryan, W. B. F., Hsü, K. J., et al., Initial Reports of the Deep Sea Drilling Project, Volume 13: Washington (U. S. Government Printing Office), p. 783-787.

McCrea, J. M., 1950. The isotopic chemistry of carbonates and a paleotemperature scale: J. Chem. Phys., v. 18, p. 849-857.

Murata, K. J., Friedman, I., and Madsen, B. M., 1969. Isotopic composition of diagenetic carbonates in marine Miocene formations of California and Oregon: U.S. Geol. Surv. Prof. Paper 614B, p. 1-24.

Parry, W. T., Reeves, C. C. Jr., and Leach, J. W., 1970. Oxygen and carbon isotopic composition of West Texas lake carbonates: Geochim. Cosmochim. Acta, v. 34, p. 825-830.

Ryan, W. B. F., Hsü, K. J., et al., 1973. Initial Reports of the Deep Sea Drilling Project, Volume 13, pts. 1-2: Washington (U. S. Government Printing Office), p. 1-1447.

Schidlowski, M., Eichmann, R., and Junge, C. E., 1976. Carbon isotope geochemistry of the Precambrian Lomagundi carbonate province, Rhodesia: Geochim. Cosmochim. Acta v. 40 , p. $449-455$.

Sharma, T. and Clayton, R. N., 1965. Measurement of $\mathrm{O}^{18}$, $\mathrm{O}^{16}$ ratios of total oxygen of carbonates: Geochim. Cosmochim. Acta, v. 29, p. 1347-1353.

Supko, P. R., Stoffers, P., and Coplen, T. B., 1974. Petrography and geochemistry of Red Sea dolomite. In Whitmarsh, R. B., Weser, O. E., Ross, D. A., et al., Initial Reports of the Deep Sea Drilling Project, Volume 23: Washington (U. S. Government Printing Office), p. 867 878.

Walters, L. J., Jr., Claypol, G. E., and Choquette, P. W., 1972. Reaction rates and $\delta \mathrm{O}^{18}$ variation for the carbonatephosphoric acid preparation method: Geochim. Cosmochim. Acta, v. 36, p. 129-140. 